\title{
Kecanduan Gawai Terhadap Cara Gaya Bersosialisasi
}

\author{
Buche Bukit Finjani ${ }^{1}$, Harry Priatno ${ }^{2}$, Yayang Fitri Fadilah ${ }^{3}$ \\ Prodi IImu Komunikasi, Fakultas Ilmu Komunikasi, Universitas Islam Nusantara
}

\begin{tabular}{|c|c|}
\hline ARTICLE INFO & ABSTRACT \\
\hline Article history: & This research is motivated by the increasing use of gadgets in the \\
\hline $\begin{array}{r}\text { Received Jan 03, } 2022 \\
\text { Revised Feb 11, } 2022 \\
\text { Accepted Maret 04, } 2022 \\
\end{array}$ & $\begin{array}{l}\text { community, this research aims to describe how the influence of gadgets } \\
\text { on social emotional development among adolescents to adults in Group } \\
6 \text { in Bandung precisely in the Binong area. The research method used }\end{array}$ \\
\hline $\begin{array}{r}\text { Keywords: } \\
\text { Candu gawai; } \\
\text { Cara bersosialisasi; } \\
\text { Gaya bersosialisasi. }\end{array}$ & $\begin{array}{l}\text { phenomenological methods. The samples in this study numbered } 9 \\
\text { people, Based on the observations we have done in the area, the } \\
\text { average use of gadgets in the area can be said to be quite high, of } \\
\text { course with this we can get diverse and accurate information from } \\
\text { informants in the area. Data retrieval techniques conducted are } \\
\text { interviews, As for several categories of informants, namely students } \\
\text { (16-18 years), teenagers or students (19-25 years) and the last there } \\
\text { are parents (26-50 years). This shows that the use of gadgets has a } \\
\text { positive influence of } 30 \% \text { and a negative influence of } 70 \% \text { on the } \\
\text { development of addiction, social, emotional, adolescents and adults in } \\
\text { group } 6 \text { in Bandung precisely in binong area. However, the influence is } \\
\text { not significant. }\end{array}$ \\
\hline
\end{tabular}

\section{ABSTRAK}

Penelitian ini dilatar belakangi oleh maraknya penggunaan gawai di masyarakat, Penelitian ini bertujuan untuk mendeskripsikan bagai mana pengaruh gawai terhadap perkembangan social emosional dikalangan remaja ke dewasa pada Kelompok 6 di bandung tepatnya di daerah Binong. Metode penelitian yang di gunakan adalah penelitian kualitatif deskriptif. Pendekatan penelitian ini menggunakan metode fenomenologi. Sampel dalam penelitian iniberjumlah 9 orang, Berdasarkan hasil observasi yang telah kami lakukan di daerah tersebut, rata-rata penggunaan gawai di daerah tersebut bisa dibilang cukup tinggi, tentunya dengan adanya hal ini kita bisa mendapatkan informasi yang beragam dan akurat dari informan yang ada di daerah tersebut. Teknik pengambilan data yang dilakukan adalah wawancara, Adapun beberapa kategori informan yaitu pelajar (16-18 tahun), remaja atau mahasiswa (19-25 tahun) dan yang terakhir ada orang tua (26-50 tahun). Hal ini menunjukan penggunaan gawai memiliki pengaruh positif sebesar $30 \%$ dan pengaruh negatif $70 \%$ terhadap perkembangan kecanduan, social, emosional,remaja dan kalangan dewasa pada kelompok 6 di bandung tepatnya di daerah Binong. Akan tetapi pengaruh tersebut tidak signifikan.

This is an open access article under the CC BY-NC license.

\section{Corresponding Author:}

Buche Bukit Finjani,

Prodi IImu Komunikasi, Fakultas IImu Komunikasi,

Universitas Islam Nusantara, Jawa Barat, Indonesia

Jl. Soekarno-Hatta No.530, Kota Bandung, Jawa Barat 40286

E-mail : buche.bukit08@gmail.com

\section{PENDAHULUAN}

Dizaman sekarang ini penggunaan gawai sudah menjadi kebiasaan dalam kehidupan sehari hari, penggunaan gawai dapat memudahkan pekerjaan manusia dari aktivitas sehari hari dan juga kita 
bisa berkomunikasi dan mendapatkan informasi secara mudah. Teknologi dewasa inisangat berperan dalam melancarkan komunikasi secara jarak jauh dan mendapatkan informasi secara efisien sehingga tugas dan pekerjaan dapat diselesaikan dengan mudah tanpa terpaku jarak. ( Sharon E. Smaldino 2011). Penciptaan teknologi gawai dilatar belakangi oleh berkembangnya kebutuhan manusia dan mempermudah kerja manusia.

Teknologi gadget (gawai) telah dikenal luas oleh masyarakat Indonesia. Hal tersebut ditunjang oleh perkembangan teknologi digital dan internet yang semakin massif. Saat ini, pengguna gawai dan internet di Indonesia cukup tinggi. Berdasarkan data riset United Nations Children's Fund (UNICEF) dan Kementerian Komunikasi dan Informasi (Kominfo) menyebutkan bahwa 84 persen masyarakat Indonesia memiliki smartphone (Kominfo, 2014). Semenatara itu, Assosiasi Pengguna Jasa Internet Indonesia (APJII) tahun 2018 melaporkan penetrasi pengguna internet Indonesia mencapai 64,8 persen atau sebanyak 171.17 juta jiwa dari total penduduk Indonesia (APJII, 2019).

Fungsi gawai yang beragam memberikan pengaruh besar dalam kehidupan sehari-hari sehingga menjadikan kebutuhan bahkan menimbulkan ketergantungan bagi penggunanya. Hal ini ditunjukan melalui tingkat frkuensi dan durasi pemakaian serta tingginya penggyna gawai. Rata-rata sebagian besar manusia akan segera terhubung dengan gawai elektronik 5 menit setelah bangun tidur dan selalu berinteraksi dengan gawai elektronik paling tidak 2 kali dalam satu jam bahkan bisa melebihi dari 200 kali per hari. Dari hasil survey yang dilakukan oleh Deloitte Mobile di Australia (2014), usia 18-24 tahun melihat smartphone 63 kali dalam satu hari, usia 24-34 tahun melihat 36 kali, usia 35-44 tahun melihat 25 kali, usia 45-54 tahun melihat 15 kali, usia 55-64 tahun melihat 13 kali, dan usia Fakultas Kedokteran Universitas Andalas 2 65-75 tahun melihat 9 kali dalam satu hari. Selain itu, masih di dalam survey yang sama, waktu yang diperlukan responden untuk melihat gawai elektronik pertama kali sejak bangun tidur (tidak termasuk mematikan alarm) pada penduduk Australia yang berusia 18-24 tahun, 10\% segera melihat gawai elektronik begitu bangun tidur, $58 \%$ dalam 5 menit, $86 \%$ dalam 30 menit pertama dan $93 \%$ dalam 60 menit setelah bangun (Deloitte, 2014).

Gawai pada mulanya diciptakan untuk mempermudah komunikasi, namun seiring perkembangan zaman memiliki tambahan fitur yang memudahkan kehidupan namun juga meiliki dampak negatif termasuk yang terjadi di Indonesia (Admar, Yakub, \& Rosmawati, 2018; Al Ayouby, 2017). Efek pancaran radiasi diyakini dapat mempengatuhi kesehatan seperti penurunan fungsi penglihatan dan pendengaran serta perubahan pola tidur yang cenderung terganggu (Tarigan, 2018; Waty \& Fourianalistyawati, 2018).

Gawai juga menyebabkan gangguan sosial seperti gangguan interaksi sosial dengan lingkungan dan berkurangnya kegiatan fisik akibat kecanduan gawai (Tarigan, 2018). Perilaku tersebut tidak lepas dari fase peralihan dari masa remaja (Darnoto, 2016). Kesibukan remaja diisi dengan gawai karena tidak ingin disebut sebagai orang gagap teknologi sehingga membawa gawai kemanapun pergi (Mawitjere, Onibala, \& Ismanto, 2017).

Berbeda dengan tujuan teknologi gawai, munculah permasalahan besar yang muncul didalam masyarakat yang mencoba teknologi gawai adalah untuk menggapai seluruh yang tersedia terkadang pengguna gawai musiman akan terkejut Ketika ia mendapatkan suatu bentuk layanan barudari jaringan internet bagai rimba belantara informasi sehingga harus dikenalkan layanan service yang efisien dan efektif. Hal demikian dilatar belakangi oleh penggunaan gawai yang tidak tepat sasaran. Gawai lebih sering digunkan untuk terjun kedalam dunia media sosial. Media sosial merupakan dunia yang memiliki berbadai macam dampak positif dan negatif, tergantung dari pengguna gawai, namun banyak permasalahn yang muncul pada akhir-akhir ini seperti munculnya kriminalitas, dan menurunnya moral dari penyalahgunaan gawai.

Kewaspadaan terbahadap perilaku kecanduan gawai harus ditingkatkan karena dapat menurunkan kualitas sehat dan kehidupan sosial remaja (Mawitjere et al., 2017; Tarigan, 2018). Gangguan kesehatan akibat penggunaan gawai pada pecandu game online diantaranya gangguan pada mata, gangguan tidur dan saraf sehingga sering pusing (Sari \& Prajayanti, 2017). Perubahan sosial masyarakat yang terjadi diantaranya pergeseran pola hidup ditandai dengan hilangnya jiwa sosial, penghormatan antar sesama menjadi masyarakat yang abai serta individual yang rawan konflik (Suryanegara, Suprajaka, \& Nahib, 2015). 


\section{METODE PENELITIAN}

Penelitian yang digunakan adalah penelitian kualitatif deskriptif. Metode penelitian deskriptif kualitatif menurut Sugiyono (2018) adalah metode penelitian yang berlandaskan filsafat postpositivisme yang biasa digunakan untuk meneliti kondisi objek yang alamiah, di mana peneliti berperan sebagai instrumen kunci dan melakukan melukiskan suatu keadaan secara objektif atau berdasarkan faktafakta yang tampak. Metode pendekatan yang digunakan dalam penelitian ini adalah pendekatan fenomenologi. Fenomenologi adalah pendekatan yang dimulai oleh Edmund Husserl dan dikembangkan oleh Martin Heidegger untuk memahami atau mempelajari pengalaman hidup manusia. Pendekatan ini berevolusi sebuah metode penelitian kualitatif yang matang dan dewasa selama beberapa dekade pada abad ke dua puluh. Fokus umum penelitian ini untuk memeriksa/meneliti esensi atau struktur pengalaman ke dalam kesadaran manusia (Tuffour: 2017).

Teknik pengumpulan data yang digunakan meliputi Wawancara, Observasi dan Dokumentasi. Menurut Sugiyono (2017) jika peneliti tidak mengetahui teknik dari pengumpulan data, maka peneliti tidak akan mendapatkan data yang dapat memenuhi standar data yang telah ditentukan. Dengan teknik yang sudah diatur, maka peneliti dapat dengan mudah melakukan penelitian. Sumber data yang digunakan adalah sumber data primer. Data primer adalah pengambilan data dengan instrumen pengamatan, wawancara, catatan lapangan dan penggunaan dokumen. Sumber data primer merupakan data yang diperoleh langsung dengan teknik wawancara informan atau sumber langsung. Sumber primer adalah sumber data yang langsung memberikan data kepada pengumpul data (Sugiyono, 2015).

Teknik analisis data yang digunakan adalah Teknik analisis data kualitatif Menurut Miles and Huberman (Sugiyono, 2017), mengemukakan bahwa aktifitas dalam analisis data kualitatif dilakukan secara interaktif dan berlangsung secara terus menerus sampai tuntas, sehingga datanya sudah jenuh, aktivitas tersebut berupa reduksi data, penyajian data dan verifikasi data.

\section{HASIL DAN PEMBAHASAN}

Penelitian akan dilakukan di salah satu daerah di bandung tepatnya di daerah Binong, berdasarkan hasil observasi yang telah kami lakukan di daerah tersebut, rata-rata penggunaan gawai di daerah tersebut bisa dibilang cukup tinggi, tentunya dengan adanya hal ini kita bisa mendapatkan informasi yang beragam dan akurat dari informan yang ada di daerah tersebut. Teknik pengambilan data yang dilakukan adalah wawancara, Adapun beberapa kategori informan yaitu pelajar (16-18 tahun), remaja atau mahasiswa (19-25 tahun) dan yang terakhir ada orang tua (26-50 tahun).

Wawancara yang dilakukan kepada 9 orang informan pada prinsipnya untuk menggali data tentang apa yang kita teliti meliputi tentang dampak gawai terhadap cara bersosialisasi. Wawancara mendalam ini bertujuan untuk menjawab pertanyaan: Pendapat anda tentang Gawai ini, dan apa dampak yang anda rasakan.

Anggapan Masyarakat Terhadap Dampak dari Penggunaan Gawai, Berbeda dengan tujuan teknologi gawai, munculah permasalahan besar yang muncul didalam masyarakat yang mencoba teknologi gawai adalah untuk menggapai seluruh yang tersedia terkadang pengguna gawai musiman akan terkejut Ketika ia mendapatkan suatu bentuk layanan barudari jaringan internet bagai rimba belantara informasi sehingga harus dikenalkan layanan service yang efisien dan efektif.

Secara garis besar perkembangan sosial emosional mencakup perkembangan emosi dan perkembangan sosial. Goleman (2016,)

Dengan belajar online yang menggunakan gawai saat ini banyak anak sekolah maupun orang dewasa yang semakin cinta gawai sehingga dunia bermainnya terlupakan, kurang bersosialisasi baik dengan teman sebaya maupun dengan keluarganya (ayah, ibu, adik, kakak, saudara) mereka lebih cinta menyendiri dengan dunianya sendiri yang masuk ke dunia gawai dimana di dalamnya dipenuhi dengan beraneka konten yang ujung ujungnya bisa mempengaruhi jiwa dan emosionalnya. Situasi ini mempengaruhi cara serta gaya hidupnya, yang menjurus ketidak stabilan emosi (cepat marah, arogan, tidak disiplin dII )

(Wawancara Dengan masyarakat Ibu Sri Yani, Tanggal 05 Juli 2021)

Penjelasan Ibu Sri Yani, menuktikan bahwa gawai saat ini sedang banyak diminati demgam berkurangnya rasa bersosialisasi baik dengan teman sebaya ataupun dengan keluaraga, mereka lebih mencintai dirinya yang berada di dunia maya. Situasi ini mempengaruhi cara serta gaya hidup yang menjurus ketidak stabilan emosi. Penggunaan gawai yang tidak diimbangi dengan 
pengawasan dapat menimbulkan dampak buruk bagi penggunaanya. Dampak yang ditimbulkanpun terhadap manusia cukup beragam dari segi kesehatan sampai sosial. Menurut Nafisa (2017)

Sangat banyak membantu karna di zaman sekarang semua ada di gawai. Dampak yang di rasakan:jika ada kumpul keluarga atau teman mereka punya kesibukannya masing masing jadi kurang nya kebersamaan untuk mengobrol,tetapi jika kita tidak bisa menggunakan gawai ini kita tidak akan mengetahui perkembangan zaman sekarang.

(Wawancara dengan masyarakat Annisa Niar Anjani, Tanggal 05 Juli 2021)

Bahkan dari anak zaman sekarang pun beberapa merasakan dari dampak gawai ini baik dampak baik maupun buruknya, seperti pada Annisa ia merasakan Ketika ia berkumpul dengan sanak saudara ia merasakan kesibukan pada masing-masing yang memegang gawai akan tetapi Annisa juga mengetahui perkembangan zaman itu dari gawainya.

Pada era globalisasi seperti saat ini, seseorang menjadi semakin mudah untuk melakukan sebuah interaksi sosial tanpa harus bersosialisasi secara langsung yaitu hanya dengan menggunakan media perantara seperti gawai. Gawai (dalam bahasa inggris: gadget) adalah suatu peranti atau instrumen yang memiliki tujuan dan fungsi praktis yang secara spesifik dirancang lebih canggih dibandingkan dengan teknologi yang diciptakan sebelumnya (Wikipedia, 2016,). Memang tidak bisa dipungkiri perkembangan zaman yang dimana mayoritas orang menggunakan gawai memiliki dampak negative fan positif dari gawai tersebut.

\section{KESIMPULAN}

Perkembangan teknologi pada zaman sekarang memasuki era globalisasi yang serba maju dan modern. Pada zaman yang modern ini, manusia dituntut untuk mengikuti perkembangan teknologi yang serba praktis yang dapat membantu didalam kehidupan manusia. Oranag- orang akan mudah melakukan komunikasi, hiburan, bahakan berbelanja sekalipun. Oleh karena itu diciptakan teknologiyang membantu manusi seperti contohnya gawai, laptop, tv, dab yang lainnya.

Gawai adalah teknologi kecil yang memiliki fungsi khusus, seringkasi diasiosasikan sebagai inovasi atau barang baru. Gawai merupakan teknologi yang di desain lebih pintar dibandingkan teknologi pada eranya, gawai merupakan teknologi yang berperan pada era globalisasi ini, sehingga sangat sulit menemukan orang yang tidak memiliki gawai. Semakin berkembang pesatnya gawai muncul juga masalah baru yang timbul dalam masyarakat yang muncul karena adanya gawai. Gawai seperti hal lainya menimbulkan efek positif dan negatif bagi penggunaya. Ketergantungan merupakan salah satu contoh nyata dari efek negatif gawai. Orang yang memiliki kecanduan gawai biasanya sangat berpengaruh buruk terhadap cara bersosialisasinya. Maka saya sebagai penulis mengingatkan bahawa suatu hal itu membpunyai dua sisi, jika kita ingin tetap postif dalam menggunakan teknologi-teknoligi yang ada hunakanlah sebaik baiknya jangan sampai anda melakukannya secara berlebihan yang membuat kita ketergantungan.

\section{Referensi}

Andari. (2013). Dampak gadget pada Perkembangan Anak. [online]. Tersedia di: http://Kumpulan-TulisanDAMPAKGADGET-PADA-PERKEMBANGANANAK.htm. Diakses pada 4 Desember 2021

Budyatna, M dan Ganiem, L.M. (2011). Teori Komunikasi Antar Pribadi. Jakarta: Kencana.

CNN Indonesia. (2015). Tingkat Kecanduan Gadget di Usia Dini Semakin Mengkhawatirkan. [online]. Tersedia di: http:// m.cnnindonesia.com/teknologi/20151103 093518 - 185 - 89078 /tingkatkecanduan-gadgetdi-usia-dini-semakinmengkhawatirkan.htm. Diakses 07 Maret 2017.

Dyah (2009). Hubungan antara kontrol diri dengan kecanduan internet pada siswa sekolah menengah pertama. Fakultas psikolog Universitas Muhammdiyah.

Effendy, O. U. (2013). Ilmu Komunikasi Teori dan Praktek. PT. Bandung: Remaja Rosdakarya.

Goleman, D. (2016). Social Intelligence. Jakarta: PT. Gramedia Pustaka Utama.

Hafidh, Faisal "PERAN PENDIDIKAN KEWARGANEGARAAN DI ERA GLOBALISASI DALAM MENUMBUHKAN SEMANGAT NASIONALISME" pada Fakultas Tarbiyah dan Keguruan UIN ArRaniry Darussalam Banda Aceh

Ibrahim (2012). Konsep diri dalam Komunikasi.

Ibrahim. 2009. Komunikasi Antarbudaya. Pontianak: STAIN Press.

Pengertian Smartphone menurut para ahli (Williams dan Sawyer) https://www.indonesiastudents.com/pengertian-smartphone-menurut-para-ahli/ diakses pada 5desember 2021. 